\title{
Stridor is not always croup: infantile haemangioma in the airway
}

\author{
Joana Cunha Oliveira, ${ }^{1}$ Inês Azevedo, ${ }^{2}$ Augusta Gonçalves, ${ }^{1}$ Carla Moreira ${ }^{1}$
}

'Department of Pediatrics, Hospital de Braga, Braga, Portugal

${ }^{2}$ Paediatric Pneumology Unit, Paediatrics Department, Centro Hospitalar São João, Porto, Portugal

\section{Correspondence to}

Dr Joana Cunha Oliveira, joana.cunha.de.oliveira@gmail. com

Accepted 3 September 2017

\section{DESCRIPTION}

A 12-month-old boy presented with a history of respiratory distress and stridor since the first month of life. He had been repeatedly misdiagnosed as recurrent croup. The stridor was biphasic, with a more pronounced inspiratory component, and was exacerbated by agitation and supine positioning. $\mathrm{He}$ had a large posterior cervical haemangioma, whose extension had never been studied by imaging methods, and delayed growth. Flexible bronchoscopy showed a multilobulated subglottic haemangioma (SGH), occupying more than $70 \%$ of the tracheal lumen. MRI showed an angiomatous malformation with the epicentre at the hind head that extended inferiorly to the cervical planes, reaching the median line in retropharyngeal planes with inferior extension (figures 1 and 2). He underwent systemic and intralesional tracheal steroids injections with partial improvement and laser therapy at 5 years of age. Today he is an asymptomatic 14-year-old adolescent with normal growth and development.

Infantile haemangiomas are the most common vascular tumours of childhood, affecting $5 \%$ of all infants. ${ }^{1} \mathrm{SGH}$ represents $1.5 \%$ of the congenital laryngeal abnormalities. Almost $50 \%$ of them are
To cite: Oliveira JC, Azevedo I, Gonçalves A, et al. BMJ Case Rep Published Online First: [please include Day Month Year] doi:10.1136/bcr-2017222449

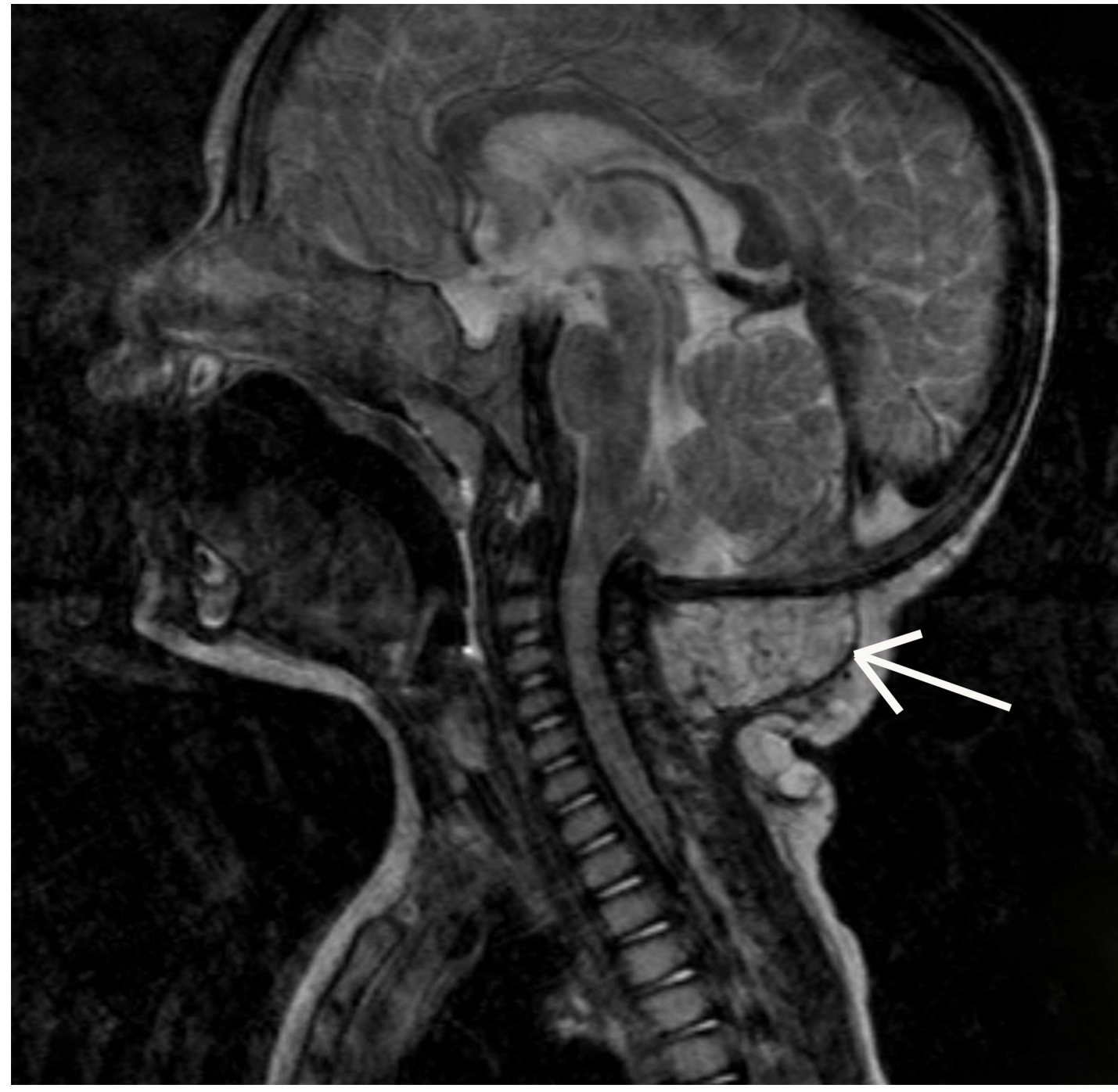

Figure 1 Cervical MRI examination, sagittal plane, showing extracranial angiomatous formation with epicentre in the posterior cervical region (white arrow). 


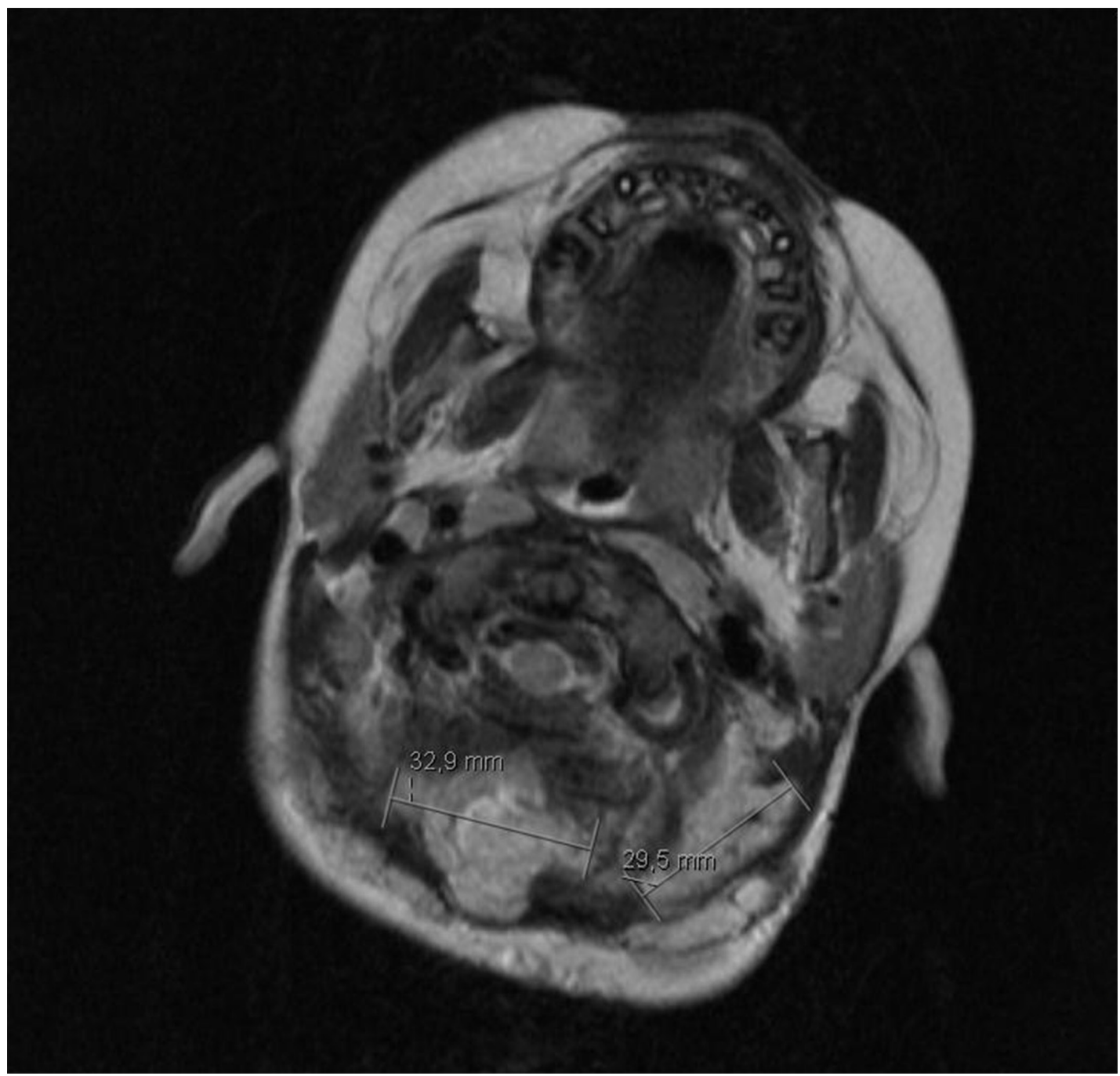

Figure 2 Cervical MRI examination, axial plane, showing multisegmented angiomatous formation that penetrates the different cervical spaces.

associated with cutaneous haemangiomas in the face. ${ }^{2}$ There is a correlation between the localisation of the cutaneous haemangioma and the risk of SGH (chin, lip, neck, preauricular region). ${ }^{2}$ Their rapid growth may lead to airway obstruction. ${ }^{2}$ Currently, when medication is warranted for infantile haemangioma, oral propranolol is the drug of first choice. ${ }^{3}$

\section{Learning points}

- The presence of cutaneous large haemangioma in the chin, lip, neck, preauricular region along with stridor/ respiratory distress, must raise a high suspicion of multilobulated subglottic haemangioma.

- Airway haemangiomas represent a potentially fatal complication of infantile haemangiomas.

- Oral propranolol is now the first-line treatment.
Contributors JCO: Follow-up of the patient, discussion of conduct, conception and design, acquisition of data, literature research and conception of the paper. IA: patient's diagnosis and treatment, literature research and revised the final version of the article. AG: patient's diagnosis and treatment, literature research and revised the final version of the article. CM: patient's diagnosis and treatment, follow-up of the patient, literature research and revised the final version of the article.

Competing interests None declared.

Patient consent Guardian consent obtained.

Provenance and peer review Not commissioned; externally peer reviewed

(C) BMJ Publishing Group Ltd (unless otherwise stated in the text of the article) 2017. All rights reserved. No commercial use is permitted unless otherwise expressly granted.

\section{REFERENCES}

1 Chen TS, Eichenfield LF, Friedlander SF. Infantile hemangiomas: an update on pathogenesis and therapy. Pediatrics 2013;131:99-108.

2 Piram M, Hadj-Rabia S, Boccara 0, et al. Beard infantile hemangioma and subglottic involvement: are median pattern and telangiectatic aspect the clue? J Eur Acad Dermatol Venereol 2016;30:2056-9.

3 Smithson SL, Rademaker M, Adams S, et al. Consensus statement for the treatment of infantile haemangiomas with propranolol. Australas J Dermatol 2017;58:155-9. 
Copyright 2017 BMJ Publishing Group. All rights reserved. For permission to reuse any of this content visit http://group.bmj.com/group/rights-licensing/permissions.

BMJ Case Report Fellows may re-use this article for personal use and teaching without any further permission.

Become a Fellow of BMJ Case Reports today and you can:

- Submit as many cases as you like

- Enjoy fast sympathetic peer review and rapid publication of accepted articles

Access all the published articles

Re-use any of the published material for personal use and teaching without further permission

For information on Institutional Fellowships contact consortiasales@bmjgroup.com

Visit casereports.bmj.com for more articles like this and to become a Fellow 